\title{
Expanded Network of Inflammatory Markers of Atherogenesis: Where Are We Now?
}

\author{
Seyed Hesameddin Abbasi ${ }^{1,2}$ and Mohammad Ali Boroumand ${ }^{2, *}$ \\ ${ }^{1}$ National Iranian Oil Company Central Hospital, Tehran, Iran \\ ${ }^{2}$ Tehran Heart Center, Tehran University of Medical Sciences, Tehran, Iran
}

\begin{abstract}
Inflammatory biomarkers play a pivotal role in atherosclerotic lesions. The plasma levels of these markers are predictive of adverse outcomes such as myocardial infarction and cardiovascular death. The immune system is involved at all stages of atherogenesis via activation of monocytes/macrophages and $\mathrm{T}$ lymphocytes. Circulating proinflammatory cytokines and chemokines produced by these cells interact with specific receptors on various cells and activate specific signaling pathways, leading to inflammation-induced atherosclerotic lesions. Recent studies have focused on predictive value of inflammatory biomarkers such as C-reactive protein and interleukin-6. These biomarkers were shown to be associated with poor quality of life and predictive of adverse events in coronary atherosclerosis and left ventricular dysfunction. Vascular predictive value of other numerous inflammatory markers is being investigated. We herein analyze the role of several mediators of inflammation, affecting vascular functions and leading toward atherosclerotic lesions.
\end{abstract}

Keywords: Inflammation, Atherosclerosis, Cytokines, C-reactive protein.

\section{INTRODUCTION}

Inflammatory biomarkers play a pivotal role in the initiation and propagation of atherosclerosis. Inflammation accompanies coronary artery spasm, impaired coronary blood flow, myocardial ischemia and restenosis after angioplasty [1-3]. Surprisingly, the first inflammatory characteristics of atherosclerotic lesions were presented by European surgeons almost two centuries ago [4]. However, atherosclerosis was categorized to inflammatory diseases by Russell Ross in 1999 [5].

Vascular endothelial dysfunction and lipoprotein retention in the arterial intima are the earliest events in atherogenesis that promote the release of cytokines and chemokines, both of which are responsible for leukocyte recruitment. These events followed by activation of $\mathrm{T}$ lymphocytes, particularly $\mathrm{T}$ helpers, which facilitate cascade of events related to oxidized low density lipoproteins (LDL) [6, 7]. Circulating pro-inflammatory cytokines produced by monocytes/ macrophages and $\mathrm{T}$ lymphocytes interact with platelet derived inflammatory and prothrombotic agents and activate specific signaling pathways, initiating cells adhesion, apoptosis and increased permeability of the endothelium. These cytokines are also responsible for oxidative stress [8].

Recent studies have demonstrated vascular predictive value of several inflammatory markers [9-11] and association of these markers with established cardiovascular risk factors, such as dyslipidemia, cigarette smoking, hypertension,

\footnotetext{
*Address correspondence to this author at the Pathology and Laboratory Medicine Department, Tehran Heart Center, Tehran University of Medical Sciences, Jalal Al Ahmad and North Karegar Cross, Zip Code: 1411713138, Tehran, Iran; Tel: +98 21 88029231; Fax: +98 21 88029230;

E-mail: borumand@sina.tums.ac.ir
}

diabetes, obesity [12-16]. Oxidation of LDL and modification of other lipoproteins induce overexpression of inflammatory cytokines and other mediators of inflammation in vessels [17-20]. Studies on the link between hypertension and inflammation have also shown that angiotensin II can lead toward hypertension through activation of inflammatory cascades and atherogenesis [21]. It is also known that hyperglycemic profiles in diabetes are associated with overproduction of pro-inflammatory cytokines by vascular endothelial cells [22]. In obese subjects, the adipose tissue can synthesize cytokines (e.g., tumor necrosis factor alpha [TNF- $\alpha$ ] and interleukin-6 [IL-6]) and, thus, promote inflammatory atherogenesis [23].

Recent studies have also shown that suppression of diverse inflammatory mediators may retard atherosclerotic process. Interestingly, evidence indicates that knockout of interferon- $\gamma$ (IFN- $\gamma$ ) [24] and interleukin-18 (IL-18) [25, 26] is crucial for retardation of atherosclerosis. Established cardiovascular risk factors modification can reduce levels of circulating inflammatory markers and improve endothelial function [27]. The atherogenic role of inflammation has also been confirmed within the frames of chronic low- and highgrade inflammatory disorders such as diabetes, periodontal disease, familial Mediterranean fever, lupus, antiphospholipid syndrome, rheumatoid arthritis, systemic sclerosis, endstage renal disease [28-32].

We herein analyze the role of several mediators of inflammation, affecting vascular functions and leading toward atherosclerotic lesions.

\section{C-REACTIVE PROTEIN (CRP)}

Acute-phase reactants are produced in response to trauma, tissue necrosis, infections and inflammation. There 
are two important sources of CRP implicated in atherothrombosis: local production in atherosclerotic plaques and in adipose tissue [33]. CRP is able to stimulate production of plaque-destabilizing matrix metalloproteinases (MMPs) and monocyte chemoattractant protein 1 (MCP-1). It also can decrease activity of endothelial nitric oxide synthase (eNOS) and impair endothelium-dependent vasodilation [34].

High sensitivity CRP (hs-CRP) levels have been proved to be strongly predictive of cardiovascular events and potentially associated with the severity of coronary atherosclerosis [35-39]. Utility of this biomarker for cardiovascular risk stratification in populations with and without established cardiovascular disease is supported by strong evidence [40]. In particular, it was shown that survival rate following percutaneous coronary intervention in patients with angina was significantly low in those with high CRP levels [41]. Not less importantly, very high levels of CRP were associated with poor quality of life, high incidence of depressive symptoms and physical inactivity [42]. Associations were also found between hs-CRP and ischemic heart disease, left ventricular ejection fraction, congestive heart failure $[43,44]$.

Four CRP polymorphisms were associated with 64\% increase in CRP levels, resulting in predicted increased risk of ischemic heart disease and ischemic cerebrovascular disease by $32 \%$ and $25 \%$, respectively [45].

\section{FIBRINOGEN}

Fibrinogen contributes to atherosclerosis through several mechanisms: 1. propagation of atherosclerosis via adhesion of white blood cells to the endothelium, stimulation of smooth muscle cells (SMCs) proliferation and release of endothelium-derived growth factor; 2 . aggregation of platelets; 3 . increase of plasma viscosity [46, 47]. Fibrinogen may play an active role in the development and destabilization of atherosclerotic plaques. Several prospective trials have demonstrated strong vascular predictive value of this biomarker [48-52]. In one study, adjusted hazard ratio for atherosclerosis progression for the highest quartile of baseline fibrinogen was 2.45 [53]. It was also suggested that this hazard ratio can be especially high in younger patients [54]. Population studies allowed to suggest that high prevalence of cardiovascular disease can be genetically determined and linked to locus in the $7^{\text {th }}$ pair of chromosome encoding fibrinogen [55]. Findings have also indicated that high fibrinogen levels and genetic variation in fibrinogen- $\alpha$ and fibrinogen- $\gamma$ genes may be associated with arterial stiffness [56].

\section{SERUM AMYLOID A (SAA)}

SAA belongs to the family of apolipoproteins. SAA is produced by liver and reticuloendothelial tissue in response to inflammatory stimuli, and circulates in complex with high density lipoprotein (HDL). It has been suggested that SAA can stimulate pro-inflammatory cytokines production by monocytes/macrophage and thereby contribute to the proinflammatory state in coronary artery disease [57]. Furthermore, the role of SAA in the prediction of cardiovascular events has been proved [58].

\section{TUMOR NECROSIS FACTOR ALPHA (TNF- $\alpha)$}

TNF- $\alpha$ is a secretory product of macrophages that activates endothelial cells, stimulates angiogenesis, and induces proliferation of SMCs. The expression of TNF- $\alpha$ in both intimal and medial SMCs and macrophages is associated with the progression of atherosclerosis [59]. Significant correlation was found between TNF- $\alpha$ and severity of coronary artery disease assessed by the number of obstructed coronary vessels and the Gensini severity score [60].

TNF- $\alpha$ is actively involved in the progression of atherosclerosis [61-63]. It was demonstrated that elevated soluble TNF receptor 1 (sTNF-R1) can predict cardiovascular mortality in patients with chronic heart failure [64]. Activity of $\mathrm{TNF}$ and its receptor may also has additive role in atherosclerosis induced by homocysteine in patients with diabetes [65].

\section{MONOCYTE CHEMOATTRACTANT PROTEIN-1 (MCP-1)}

MCP-1 is a member of the CC chemokine superfamily that activates monocytes at acute stage of inflammation. MCP-1 induces migration of monocytes/macrophages, as well as CD4+ and CD8+ T lymphocytes into the subendothelial space [66-69]. MCP-1 expression can be induced by IL-1b and TNF-alpha through the activation of nuclear factor-kB [70, 71]. MCP-1 facilitates oxidation of cholesterol and through it contributes to the development of fatty streaks in hypercholesterolemia [72]. Interestingly, MCP-1 inhibition in apolipoprotein-E knockout mice prevents atherogenesis [73].

\section{INTERLEUKIN-6 (IL-6)}

IL-6 is a well-known risk marker of cardiovascular disease associated with obesity, type 2 diabetes and myocardial infarction. The relationship between IL-6, the Gensini severity score and $>70 \%$ stenosis of coronary vessels has been already proved [74, 75]. IL-6 levels are also independently associated with subclinical atherosclerotic lesions [76, 77], and proved to be predictive of ischemic events [78].

IL-6 induces secretion of other inflammatory markers, particularly CRP. IL-6 activates cell-surface signaling via the assembly of IL-6, its receptor (IL-6R) and signaling receptor gp130 [79]. Haddya et al., demonstrated positive correlation between IL-6, TNF- $\alpha$ and CRP in parents and their offsprings. Furthermore, they found negative relationship between IL-6 and HDL-cholesterol [80].

\section{INTERLEUKIN-8 (IL-8)}

IL-8 is another cytokine, mediator of angiogenesis in coronary atherosclerosis, inducing migration and proliferation of endothelial cells and smooth muscle cells [81]. Recently, macrophages from atherosclerotic plaques were found to express the IL-8 receptor (CXCR2). This expression is pro-atherogenic. CXCR2 deficiency retards progression of atherosclerosis in animal models [82]. Besides, elevated levels of IL-8 are associated with an increased risk of coronary artery disease [83]. 


\section{INTERLEUKIN-1 (IL-1)}

IL-1 is a pro-inflammatory cytokine that increases production of other cytokines and induces expression of adhesion molecules on endothelial cells. In addition, IL-1 contributes to the tissue damage by stimulating cell proliferation and release of matrix metalloproteinases. Overexpression of IL-1 receptor antagonist (IL-1Ra) inhibits the development of atherosclerotic lesions. Moreover, inhibition of IL-1 $\beta$ decreases severity of atherosclerosis through the increased expression of VCAM-1 and MCP-1 [84, 85].

\section{INTERLEUKIN-4 (IL-4)}

Deficiency of IL-4 can reduce atherosclerotic lesions [86]. This cytokine increases the number of cell-surface binding sites for LDL. IL-4 can have profound effect on the macrophage lipid metabolism within atherosclerotic lesions [87].

\section{INTERLEUKIN-10 (IL-10)}

The role of IL-10 in the inflammatory process is dual, pro- and anti-inflammatory [88]. Cumulative incidence of coronary artery disease was significantly greater in individuals with IL-10 concentrations $\geq 1.04 \mathrm{pg} / \mathrm{Ml}$ and one standard deviation increase in baseline IL-10 concentration was associated with a $34 \%$ greater risk of this event [89]. This interleukin is expressed in human atherosclerotic plaques, and it can modulate local inflammatory response by preventing excessive cell death in the plaque [90]. In a study on animal models, increased T-cell infiltration, abundant interferongamma expression and decreased collagen content were shown in the atherosclerotic lesions of IL-10-deficient mice. IL-10 appeared to be crucial for protection against the effect of environmental pathogens on atherosclerosis [91].

\section{INTERLEUKIN-12 (IL-12)}

Recent data suggest that IL-12 plays an active role in regulating immune response during initial atherosclerotic changes in animal models. Daily administration of IL-12 was shown to increase serum levels of antibodies against oxidized LDL [92]. IL-12 can also induce T lymphocytes recruitment into atherosclerotic plaque [93].

\section{INTERLEUKIN-15 (IL-15)}

Plasma levels of IL-15 were found to be high in patients with coronary artery disease, compared to those without coronary artery disease [94]. This cytokine is up-regulated in atherosclerotic lesions, where it stimulates recruitment of $\mathrm{T}$ lymphocytes [95]. The expression of IL-15 is found almost exclusively in fibrolipid and lipid-rich plaques in complex foam cells [96].

\section{INTERLEUKIN-18 (IL-18)}

IL-18 is a pro-inflammatory cytokine secreted by mononuclear cells. The serum concentrations of this cytokine have been shown to be predictive of mortality in coronary artery disease [97]. Patients in the highest quartile for this marker had greater risk of cardiovascular death, compared to those in the lowest quartile [98]. Recent findings have indicated a role of IL-18 in progression of atherosclerosis at its early and late stages [99]. It has also been shown that, despite increased activity of $\mathrm{T}$ lymphocytes and increased serum levels of cholesterol, there is no progression of atherosclerosis in the absence of IL-18 [100]. Pro-atherogenic effect of IL-18 is strongly dependent on IFN- $\gamma$ produced by T lymphocytes, macrophages, natural killer cells and vascular cells [101].

\section{INTERLEUKIN-33 (IL-33)}

IL-33 is a member of the IL-1 family that induces differentiation of T lymphocytes and is involved in T-cell mediated immune responses. IL-33 regulates production of IL-5, IL-4, IL-13 and can decrease levels of IFN- $\gamma$ in the serum and lymph nodes [102]. It is also involved in the production of antibodies against oxidized LDL [103].

\section{INTERCELLULAR ADHESION MOLECULE-1 (ICAM-1)}

ICAM-1 is a member of the immunoglobulin superfamily. Its role relates to leukocytes migration into tissues. ICAM-1 can contribute to inflammatory responses within the blood vessel wall by increasing endothelial cell activation and augmenting atherosclerotic plaque formation. Its expression is up-regulated in atherosclerotic plaques in human coronary arteries [104, 105]. Besides, it was shown that soluble ICAM-1 is correlated with the severity of atherosclerosis, that its inhibition can retard atherogenesis [106-108] and that ICAM-1 can serve as a predictor of vascular events [109].

\section{VASCULAR CELL ADHESION MOLECULE-1 (VCAM-1)}

VCAM-1 facilitates adhesion of most inflammatory cells (monocytes, lymphocytes, eosinophils etc.) to the vascular wall and monocytes recruitment into atherosclerotic sites [110].

\section{METALLOPROTEINASES (MMPS)}

Monocyte/macrophage-derived MMPs are zincdependent endoproteases with collagenase and/or gelatinase activity [111]. These agents damage the endothelium and collagen fibrils in atherosclerotic plaques, thus accelerating the process of atherothrombosis [112-116].

\section{CONCLUDING REMARKS}

Clinical implications of inflammation in atherosclerosis have been acknowledged in the past decade. Diverse markers of inflammation have been associated with adverse vascular events and inefficiency of primary and secondary cardiovascular prevention [117]. The concept that inflammation contributes to atherosclerotic cardiovascular disease has had a remarkable impact on our understanding of atherothrombosis that is no longer considered as a reflection of lipid disorders, but rather as a disorder characterized by low-grade vascular inflammation.

Population-based studies have proved that elevated levels of several inflammatory mediators have predictive values for future coronary vascular events. In particular, some prospec- 
tive studies have demonstrated increased vascular risk associated with increased baseline levels of pro-inflammatory cytokines (IL-6 and TNF- $\alpha$ ) [118], cell adhesion molecules (ICAM-1, P-selectin, E-selectin [119] and acute-phase reactants (CRP, fibrinogen, serum amyloid A) [120]. It has recently been suggested that hs-CRP is a well validated biomarker with predictive value. Benefits of hs-CRP for stratifying the risk of atherosclerotic events have been confirmed. It is the most useful predictive marker of recurrent adverse events, including death, myocardial infarction and restenosis after cardiac revascularization [121].

In contrast to cytokines, CRP has a long half-life with stability of levels with no observable circadian variation [122]. In addition, there are well validated assays for detection of CRP in freshly frozen and stored plasma [123]. The American Heart Association and the Centers for Disease Control and Prevention have published a joint scientific statement on the use of inflammatory markers, particularly hs-CRP in clinical and public health practice. According to the statement, subjects with hs-CRP levels $<1.0 \mathrm{mg} / \mathrm{L}$ are at low risk, those with hs-CRP of $1.0-3.0 \mathrm{mg} / \mathrm{L}$ at moderate risk, and those with hs-CRP $>3.0 \mathrm{mg} / \mathrm{L}$ at high risk of of vascular events. Furthermore, subjects with unexplained, sustained elevation of hs-CRP $(>10.0 \mathrm{mg} / \mathrm{L})$ should be evaluated to exclude non-cardiovascular causes [124-126].

In one study, circulating levels of CRP were found to be significantly increased in patients with unstable angina, particularly in those who later develop an adverse vascular event. In this study, the relative risk of adverse events associated with the highest tertile of CRP levels was 5.2 [127]. In another study, CRP levels were associated with an increased incidence of major adverse cardiac events in patients with acute myocardial infarction [128]. Also, it was shown that CRP levels greater than $10 \mathrm{mg} / \mathrm{L}$ independently predict the presence of significant coronary lesions [129]. Patients with hs-CRP $>3.5 \mathrm{mg} / \mathrm{L}$ had 11-fold increased risk of cardiac events, compared with those with lower levels [130].

Elevated hs-CRP levels are associated with poor quality of life, depression, physical inactivity [42], and are predictive of poor outcomes in coronary atherosclerosis and left ventricular dysfunction [43].

The role of anti-inflammatory drugs in prevention of atherosclerotic events has not been fully elucidated. Some studies have demonstrated that anti-inflammatory drugs can be useful in prevention of scar formation after catheter procedures and vascular surgery [131]. Importantly, antiinflammatory actions of statins have been linked to their favorable effects on atherosclerosis [132]. Several other therapeutic agents with anti-inflammatory properties are being investigated in studies with experimental and clinical models of inflammation-associated atherosclerosis.

\section{REFERENCES}

[1] Sherer Y, Shoenfeld Y. Atherosclerosis. Ann Rheum Dis 2002; 61: 97-9.

[2] Li JJ. Inflammation: an important mechanism for different clinical entities of coronary artery diseases. Chin Med J (Engl) 2005; 118: 1817-26.

[3] Li JJ, Nie SP, Xu B, Guo YL, Gao Z, Zheng X. Inflammation in variant angina: is there any evidence? Med Hypotheses 2007; 68: 635-40.
[4] Kaperonis EA, Liapis CD, Kakisis JD, Dimitroulis D, Papavassiliou VG. Inflammation and atherosclerosis. Eur J Vasc Endovasc Surg 2006; 31: 386-93.

[5] Ross R. Atherosclerosis - an inflammatory disease. N Eng J Med 1999; 340: 115-26.

[6] Rodríguez G, Mago N, Rosa F. Role of inflammation in atherogenesis. Invest Clin 2009; 50: 109-29.

[7] Boyle JJ. Macrophage activation in atherosclerosis: pathogenesis and pharmacology of plaque rupture. Curr Vasc Pharmacol 2005; 3: $63-8$.

[8] Sprague AH, Khalil RA. Inflammatory cytokines in vascular dysfunction and vascular disease. Biochem Pharmacol 2009 15; 78: 539-52.

[9] Zairis MN, Adamopoulou EN, Manousakis SJ, et al. Biomarkers of Inflammation and Outcome in Acute Coronary Syndromes (BIAS) Investigators Biomarkers of Inflammation and Outcome in acute coronary Syndromes (BIAS) investigators. The impact of hs Creactive protein and other inflammatory biomarkers on long-term cardiovascular mortality in patients with acute coronary syndromes. Atherosclerosis 2007; 194: 397-402.

[10] Stoll G, Bendszus M. Inflammation and atherosclerosis: novel insights into plaque formation and destabilization. Stroke 2006; 37: 1923-32.

[11] Fan J, Watanabe T. Inflammatory reactions in the pathogenesis of atherosclerosis. J Atheroscler Thromb 2003; 10: 63-71.

[12] Tohidi M, Hadaegh F, Harati H, Azizi F. C-reactive protein in risk prediction of cardiovascular outcomes: Tehran Lipid and Glucose Study. Int J Cardiol 2009; 132: 369-74.

[13] Niccoli G, Biasucci LM, Biscione C, et al. Independent prognostic value of $\mathrm{C}$-reactive protein and coronary artery disease extent in patients affected by unstable angina. Atherosclerosis 2008; 196: 779-85.

[14] Zhang SZ, Jin YP, Qin GM, Wang JH. Association of plateletmonocyte aggregates with platelet activation, systemic inflammation, and myocardial injury in patients with non-st elevation acute coronary syndromes. Clin Cardiol 2007; 30: 26-31.

[15] Sanchez PL, Morinigo JL, Pabon P, et al. Prognostic relations between inflammatory markers and mortality in diabetic patients with non-ST elevation acute coronary syndrome. Heart 2004; 90 : 264-69.

[16] Arena R, Arrowood JA, Fei DY, Helm S, Kraft KA. The relationship between C-reactive protein and other cardiovascular risk factors in men and women. J Cardiopulm Rehabil 2006; 26: 323-27.

[17] Williams KJ, Tabas I. The response-to-retention hypothesis of atherogenesis reinforced. Curr Opin Lipidol 1998; 9: 471-74.

[18] Witztum JL, Berliner JA. Oxidized phospholipids and isoprostanes in atherosclerosis. Curr Opin Lipidol 1998; 9: 441-48.

[19] Dichtl W, Nilsson L, Goncalves I, et al. Very low-density lipoprotein activates nuclear factor- $\mathrm{\kappa B}$ in endothelial cells. Circ Res 1999; 84: 1085-94.

[20] Mackness MI, Mackness B, Durrington PN. Paraoxonase and coronary heart disease. Curr Opin Lipidol 1998; 9: 319-24.

[21] Libby P. Inflammation: a common pathway in cardiovascular diseases. Dialog Cardiovasc Med 2003; 8: 59-73.

[22] Schmidt AM, Yan SD, Wautier JL, Stern D. Activation of receptor for advanced glycation end products: a mechanism for chronic vascular dysfunction in diabetic vasculopathy and atherosclerosis. Circ Res 1999; 84: 489-97.

[23] Yudkin JS, Stehouwer CD, Emeis JJ, Coppack SW. C-reactive protein in healthy subjects: associations with obesity, insulin resistance, and endothelial dysfunction: a potential role for cytokines originating from adipose tissue? Arterioscler Thromb Vasc Biol 1999; 19: 972-78.

[24] Gupta S, Pablo AM, Jiang X, Wang N, Tall AR, Schindler C. IFN- $\gamma$ potentiates atherosclerosis in ApoE knock-out mice. J Clin Invest 1997; 99: 2752-61.

[25] Elhage R, Jawien J, Rudling M, et al. Reduced atherosclerosis in interleukin-18 deficient apolipoprotein E-knockout mice. Cardiovasc Res 2003; 59: 234-40.

[26] Tenger C, Sundborger A, Jawien J, Zhou X. IL-18 accelerates atherosclerosis accompanied by elevation of IFN- $\gamma$ and CXCL16 expression independently of $\mathrm{T}$ cells. Arterioscler Thromb Vasc Biol 2005; 25: 791-96.

[27] Harris GD, White RD. Lifestyle modifications for the prevention and treatment of cardiovascular disease: an evidence-based approach. Mol Med 2004; 101: 222-6. 
[28] Zoccali C, Mallamaci F, Tripepi G. Inflammatory proteins as predictors of cardiovascular disease in patients with endstage renal disease. Nephrol Dial Transplant 2004; 19: 67-72.

[29] Maradit-Kremers H, Crowson CS, Nicola PJ. Increased unrecognized coronary heart disease and sudden deaths in rheumatoid arthritis. Arthritis Rheum 2005; 52: 402-11.

[30] Shovman O, Gilburd B, Shoenfeld Y. The role of inflammatory cytokines in the pathogenesis of systemic Lupus erythematosus- related atherosclerosis: a novel target for treatment. J Rheumatol 2006; 33: 445-7.

[31] Deliargyris EN, Madianos PN, Kadoma W, et al. Periodontal disease in patients with acute myocardial infarction: prevalence and contribution to elevated C-reactive protein levels. Am Heart J 2004; 147: 1005-9.

[32] Gasparyan AY, Ugurlucan M. The emerging issue of cardiovascular involvement in familial Mediterranean fever. Arch Med Sci 2008; 4: 465-67.

[33] Saijo Y, Utsugi M, Yoshioka E, et al. Inflammation as a cardiovascular risk factor and pulse wave velocity as a marker of early-stage atherosclerosis in the Japanese population. Environ Health Prev Med 2009; 14:159-64.

[34] Qamirani E, Ren Y, Kuo L, Hein TW. C-reactive protein inhibits endothelium-dependent NO-mediated dilation in coronary arterioles by activating p38 kinase and NAD(P)H oxidase. Arterioscler Thromb Vasc Biol 2005; 25: 995-1001.

[35] Boroumand MA, Sotoudeh AM, Sheikhvatan M, Saadat S, Abbasi SH, Sheikhfathollahi M. Do C-reactive protein and lipoprotein (a) have different impacts on the severity of coronary artery disease in diabetic and non-diabetic patients? J Tehran Univ Heart Cent 2008; 3: $163-8$.

[36] Sabatine MS, Morrow DA, Jablonski KA, et al. PEACE investigators. Prognostic significance of the centers for disease control/ American heart association high-sensitivity C-reactive protein cut points for cardiovascular and other outcomes in patients with stable coronary artery disease. Circulation 2007; 115: 1528-36.

[37] Calabrò P, Golia E, Yeh ET. CRP and the risk of atherosclerotic events. Semin Immunopathol 2009; 31: 79-94.

[38] Bisoendial RJ, Birjmohun RS, Akdim F, et al. C-reactive protein elicits white blood cell activation in humans. Am J Med 2009; 122: 582-9.

[39] Van Der Meer IM, De Maat MP, Hak AE, et al. C-reactive protein predicts progression of atherosclerosis measured at various sites in the arterial tree: the Rotterdam study. Stroke 2002; 33: 2750-5.

[40] Bard RL, Clarke N, Rubenfire M, Eagle K, Brook RD. P-594: cardiovascular risk stratification obtained by Framingham risk score and C-reactive protein measurement. Am J Hypertens 2005; 18: 224 .

[41] Imai K, Okura H, Kume T, et al. C-reactive protein predicts nontarget lesion revascularization and cardiac events following percutaneous coronary intervention in patients with angina pectoris. J Cardiol 2009; 53: 388-95.

[42] García-Lorda P, Bulló M, Balanzà R, Salas-Salvadó J. C-reactive protein, adiposity and cardiovascular risk factors in a Mediterranean population. Int J Obes (Lond) 2006; 30: 468-74.

[43] Arroyo-Espliguero R, Avanzas P, Quiles J, Kaski JC. C-reactive protein predicts functional status and correlates with left ventricular ejection fraction in patients with chronic stable angina. Atherosclerosis 2009; 205: 319-24.

[44] Cushman M, Arnold AM, Psaty BM, et al. C-reactive protein and the 10-year incidence of coronary heart disease in older men and women: the cardiovascular health study. Circulation 2005; 112: 2531.

[45] Zacho J, Tybjaerg-Hansen A, Jensen JS, Grande P, Sillesen H, Nordestgaard BG. Genetically elevated C-reactive protein and ischemic vascular disease. N Engl J Med 2008; 359: 1897-908.

[46] Heinrich J, Assmann G. Fibrinogen and cardiovascular risk. J Cardiovasc Risk 1995; 2: 197-205.

[47] Andreotti F, Burzotta F, Maseri A. Fibrinogen as a marker of inflammation: a clinical view. Blood Coagul Fibrinol 1999; 10: 34.

[48] Levenson J, Giral P, Razavian M, Gariepy J, Simon A. Fibrinogen and silent atherosclerosis in subjects with cardiovascular risk factors. Arterioscler Thromb Vasc Biol 1995; 15: 1263-8.

[49] Broadhurst P, Kelleher C, Hughes K, Imeson JD, Raftery EB. Fibrinogen, factor VII clotting activity and coronary artery disease severity. Atherosclerosis 1990; 85: 169-73.
[50] Meade TW, Mellows S, Brozovic M, et al. Haemostatic function and ischemic heart disease: principal results of the Northwick park heart study. Lancet 1986; 2: 533-7.

[51] Kannel WB, Wolf PA, Castelli WP, D'Agostino RB. Fibrinogen and risk of cardiovascular disease, the Framingham study. JAMA 1987; 258: 1186-3.

[52] Yarnell JW, Baker IA, Sweetnam PM, et al. Fibrinogen, viscosity, and white blood cell count are major risk factors for ischemic heart disease. The caerphilly and speedwell collaborative heart disease studies. Circulation 1991; 83: 836-44.

[53] Sabeti S, Exner M, Mlekusch W, et al. Prognostic impact of fibrinogen in carotid atherosclerosis. Stroke 2005; 36: 1400-4.

[54] Green D, Foiles N, Chan C, Schreiner PJ, Liu K. Elevated fibrinogen levels and subsequent subclinical atherosclerosis: the CARDIA study. Atherosclerosis 2009; 202: 623-31.

[55] Best LG, North KE, Li X, et al. Linkage study of fibrinogen levels: the strong heart family study. BMC Med Genet 2008; 9: 77.

[56] Sie MP, Isaacs A, de Maat MP, et al. Genetic variation in the fibrinogen-alpha and fibrinogen-gamma genes in relation to arterial stiffness: the Rotterdam study. J Hypertens 2009; 27: 1392-8.

[57] Song C, Shen Y, Yamen E, et al. Serum amyloid A may potentiate prothrombotic and proinflammatory events in acute coronary syndromes. Atherosclerosis 2009; 202: 596-604.

[58] Zakynthinos E, Pappa N. Inflammatory biomarkers in coronary artery disease. J Cardiol 2009; 53: 317-33.

[59] Lei X, Buja LM. Detection and localization of tumor necrosis factor- $\alpha$ in WHHL rabbit arteries. Atherosclerosis 1996; 125: 81-9.

[60] Gotsman I, Stabholz A, Planer D, et al. Serum cytokine tumor necrosis factor-alpha and interleukin- 6 associated with the severity of coronary artery disease: indicators of an active inflammatory burden? Isr Med Assoc J 2008; 10: 494-8.

[61] Brånén L, Hovgaard L, Nitulescu M, Bengtsson E, Nilsson J, Jovinge $\mathrm{S}$. Inhibition of tumor necrosis factor- $\alpha$ - reduces atherosclerosis in apolipoprotein e knockout mice. Arterioscler Thromb Vasc Biol 2004; 24: 2137-42.

[62] Boesten LS, Zadelaar AS, van Nieuwkoop A, et al. Tumor necrosis factor- $\alpha$ promotes atherosclerotic lesion progression in APOE*3Leiden transgenic mice. Cardiovasc Res 2005; 66: 179-85.

[63] Bruunsgaard H, Skinhøj P, Pedersen AN, Schroll M, Pedersen BK. Ageing, tumor necrosis factor- $\alpha(\mathrm{TNF}-\alpha)$ and atherosclerosis. Clin Exp Immunol 2008; 121: 255-60.

[64] Rauchhaus M, Doehner W, Francis DP, et al. Plasma cytokine parameters and mortality in patients with chronic heart failure. Circulation 2000; 102: 3060-7.

[65] Taniguchi A, Fukushima M, Nakai Y, et al. Soluble tumor necrosis factor receptor 1 is strongly and independently associated with serum homocysteine in nonobese japanese type 2 diabetic patients. Diabetes Care 2006; 29: 949-50.

[66] Taub DD, Proost P, Murphy WJ, et al. Monocyte chemotactic protein-1 (MCP-1), -2 , and -3 are chemotactic for human T lymphocytes. J Clin Invest 1995; 95: 1370-6.

[67] Lu Y, Cai Z, Galson DL, et al. Monocyte chemotactic protein-1 (MCP-1) acts as a paracrine and autocrine factor for prostate cancer growth and invasion. Prostate 2006; 66: 1311-8.

[68] Gosling J, Slaymaker S, Gu L, et al. MCP-1 deficiency reduces susceptibility to atherosclerosis in mice that overexpress human apolipoprotein B. J Clin Invest 1999; 103: 773-8.

[69] Boring L, Gosling J, Cleary M, Charo IF. Decreased lesion formation in CCR2-/- mice reveals a role for chemokines in the initiation of atherosclerosis. Nature 1998; 394: 894-7.

[70] Chikaraishi A, Hirahashi J, Takase O, et al. Tranilast inhibits interleukin-1beta-induced monocyte chemoattractant protein-1 expression in rat mesangial cells. Eur J Pharmacol 2001; 427: 1518 .

[71] Libby P, Sukhova G, Lee RT, Galis ZS. Cytokines regulate vascular functions related to stability of the atherosclerotic plaque. J Cardiovasc Pharmacol 1995; 25: 9-12.

[72] Chen YL, Chang YJ, Jiang MJ. Monocyte chemotactic protein-1 gene and protein expression in atherogenesis of hypercholesterolemic rabbits. Atherosclerosis 1999; 143: 115-123.

[73] Ni W, Kitamoto S, Ishibashi M, et al. Monocyte chemoattractant protein-1 is an essential inflammatory mediator in angiotensin IIinduced progression of established atherosclerosis in hypercholesterolemic mice. Arterioscler Thromb Vasc Biol 2004; 24: 534-9.

[74] Gotsman I, Stabholz A, Planer D, et al. Serum cytokine tumor necrosis factor- $\alpha$ and interleukin- 6 associated with the severity of 
coronary artery disease: indicators of an active inflammatory burden? Isr Med Assoc J 2008; 10: 494-8.

[75] Rott D, Zhu J, Fu Zhou Y, Burnett MS, Zalles-Ganley A, Epstein SE. IL-6 is produced by splenocytes derived from CMV-infected mice in response to $\mathrm{CMV}$ antigens, and induces MCP-1 production by endothelial cells: a new mechanistic paradigm for infectioninduced atherogenesis. Atherosclerosis 2003; 170: 223-8.

[76] Amar J, Fauvel J, Drouet L, et al. Interleukin 6 is associated with subclinical atherosclerosis: a link with soluble intercellular adhesion molecule 1. J Hypertens 2006; 24: 1083-8.

[77] Saremi A, Anderson RJ, Luo P, et al. Association between IL-6 and the extent of coronary atherosclerosis in the veterans affairs diabetes trial (VADT). Atherosclerosis 2009; 203: 610-4.

[78] Huber SA. Interleukin-6 exacerbates early atherosclerosis in mice. Arterioscler Thromb Vasc Biol 1999; 19: 2364-7.

[79] Abeywardena MY, Leifert WR, Warnes KE, Varghese JN, Head RJ. Cardiovascular biology of interleukin-6. Curr Pharm Des 2009; 15: 1809-21.

[80] Haddya N, Sassa C, Droescha S, et al. IL-6, TNF- $\alpha$ and atherosclerosis risk indicators in a healthy family population: the STANISLAS cohort. Atherosclerosis 2003; 170: 277-83.

[81] Simonini A, Moscucci M, Muller DW, et al. IL-8 is an angiogenic factor in human coronary atherectomy tissue. Circulation 2000; 101: 1519-26.

[82] Boisvert WA, Curnss LK, Terkeltaub RA. Interleukin-8 and its receptor CXCR2 in atherosclerosis. Immunol Res 2000; 21: 12937.

[83] Boekholdt SM, Peters RJ, Hack CE, et al. IL-8 plasma concentrations and the risk of future coronary artery disease in apparently healthy men and women. Arterioscler Thromb Vasc Biol 2004; 24 : 1503-8.

[84] Hirokazu K, Tamikazu N, Yasuhiro Y, et al. Lack of interleukin-1 $\beta$ decreases the severity of atherosclerosis in ApoE-deficient mice. Arterioscler Thromb Vasc Biol 2003; 23: 656-60.

[85] Merhi-Soussia F, Kwakc BR, Magnea D, et al. Interleukin-1 plays a major role in vascular inflammation and atherosclerosis in male apolipoprotein E-knockout mice. Cardiovasc Res 2005; 66: 583-93.

[86] King VL, Szilvassy SJ, Daugherty A. Interleukin-4 deficiency decreases atherosclerotic lesion formation in a site-specific manner in female LDL receptor-/- mice. Arterioscler Thromb Vasc Biol 2002; 22: 456-61.

[87] Cornicellia JA, Butteigerb D, Raterib DL, Welcha K, Daugherty A. Interleukin-4 augments acetylated LDL-induced cholesterol esterification in macrophages. J Lipid Res 2000; 41: 376-83.

[88] Kahraman S, Yilmaz R, Arici M, et al. IL-10 genotype predicts serum levels of adhesion molecules, inflammation and atherosclerosis in hemodialysis patients. J Nephrol 2006; 19: 50-56.

[89] Lakoskia SJ, Liub Y, Bridget Brosnihanc K, Herrington DM. Interleukin-10 concentration and coronary heart disease (CHD) event risk in the estrogen replacement and atherosclerosis (ERA) study. Atherosclerosis 2008; 197: 443-7.

[90] Mallat Z, Heymes C, Ohan J, Faggin E, Lesèche G, Tedgui A. Expression of interleukin-10 in advanced human atherosclerotic plaques: relation to induci. Arterioscler Thromb Vasc Biol 1999; 19: 611-6.

[91] Mallat Z, Besnard S, Duriez M, et al. Protective role of interleukin10 in atherosclerosis. Circulation Res 1999; 85: 17-24.

[92] Lee TS, Yen HC, Pan CC, Chau LY. The role of interleukin 12 in the development of atherosclerosis in ApoE-deficient mice. Arterioscler Thromb Vasc Biol 1999; 19: 734-42.

[93] Zhang X, Niessner A, Nakajima T, et al. Interleukin 12 Induces Tcell recruitment into the atherosclerotic plaque. Circ Res 2006; 98 : 434-6.

[94] Masaharu K, Mitsuru O, Norihisa I, et al. Serum interleukin-15 concentration in patients with essential hypertension. Am J Hypertens 2005; 18: 1019-25.

[95] Wuttge DM, Eriksson P, Sirsjö A, Hansson GK, Stemme S. Expression of interleukin-15 in mouse and human atherosclerotic lesions. Am J Pathol 2001; 159: 417-23.

[96] Houtkamp MA, van der Wal AC, de Boer OJ, et al. Interleukin-15 expression in atherosclerotic plaques an alternative pathway for T-cell activation in atherosclerosis? Arterioscler Thromb Vasc Biol 2001; 21:1208-13.

[97] Nakamura A, Shikata K, Hiramatsu M, et al. Serum Interleukin-18 levels are associated with nephropathy and atherosclerosis in
Japanese patients with type 2 diabetes. Diabetes Care 2005; 28 : 2890-5.

[98] Mallat Z, Corbaz A, Scoazec A, et al. Interleukin-18/interleukin-18 binding protein signaling modulates atherosclerotic lesion development and stability. Circ Res 2001; 89: 41-5.

[99] Yearley JH, Xia D, Pearson GB, Carville A, Shannon RP, Mansfield $\mathrm{KG}$. Interleukin-18 predicts atherosclerosis progression in SIV-infected and uninfected rhesus monkeys (Macaca mulatta) on a high-fat/high-cholesterol diet. Lab Invest 2009; 89: 657-67.

[100] Elhage R, Jawien J, Rudling M, et al. Reduced atherosclerosis in interleukin-18 deficient apolipoprotein E-knockout mice. Cardiovasc Res 2003; 59: 234-40.

[101] Tenger C, Sundborger A, Jawien J, Zhou X. IL-18 accelerates atherosclerosis accompanied by elevation of IFN- $\gamma$ and CXCL16 expression independently of T-cells. Arterioscler Thromb Vasc Biol 2005; 25:791-9.

[102] Castellani ML, Kempuraj DJ, Salini V, et al. The latest interleukin: IL-33 the novel IL-1-family member is a potent mast cell activator. J Biol Regul Homeost Agents 2009; 23: 11-4.

[103] Miller AM, Xu D, Asquith DL, et al. IL-33 reduces the development of atherosclerosis. J Exp Med 2007; 205: 339-46.

[104] Kitagawa K, Matsumoto M, Sasaki T, et al. Involvement of ICAM1 in the progression of atherosclerosis in APOE-knockout mice. Atherosclerosis 2002; 160: 305-10.

[105] Lawson C, Wolf S. ICAM-1 signaling in endothelial cells. Pharmacol Rep 2009; 61: 22-32.

[106] Iiyama K, Hajra L, Iiyama M, et al. Patterns of vascular cell adhesion molecule-1 and intercellular adhesion molecule-1 expression in rabbit and mouse atherosclerotic lesions and at sites predisposed to lesion formation. Circ Res 1999; 85: 199-207.

[107] Nakashima Y, Raines EW, Plump AS, Breslow JL, Ross R. Upregulation of VCAM-1 and ICAM-1 at atherosclerosis-prone sites on the endothelium in the ApoE-deficient mouse. Arterioscler Thromb Vasc Biol 1998; 18: 842-51.

[108] Rohde LK, Lee RT, Rivero J, et al. Circulating cell adhesion molecules are correlated with ultrasound-based assessment of carotid atherosclerosis. Arterioscler Thromb Vasc Biol 1998;18: 1765-70.

[109] Ridker PM, Hennekens CH, Ritman-Johnson B, Stamper MJ, Allen J. Plasma concentration of soluble intercellular adhesion molecule 1 and risks of future myocardial infarction in apparently healthy men. Lancet 1998; 351: 88-92.

[110] Ley K, Huo Y. VCAM-1 is critical in atherosclerosis J Clin Invest 2001; 107: 1209-10.

[111] Goetzl EJ, Banda MJ, Leppert D. Matrix metalloproteinases in immunity. J Immunol 1996; 156: 1-4.

[112] Armstrong EJ, Morrow DA, Sabatine MS. Inflammatory biomarkers in acute coronary syndromes: part IV: matrix metalloproteinases and biomarkers of platelet activation. Circulation 2006; 113 : 382-5.

[113] Galis Z, Khatri J. Matrix metalloproteinases in vascular modeling and atherogenesis: the good, the bad, and the ugly. Circ Res 2003; 90: 251-62.

[114] Creemers E, Cleutjens J, Smits J, Daemen M. Matrix metalloproteinase inhibition after myocardial infarction: a new approach to prevent heart failure? Circ Res 2001; 89: 201-10.

[115] Galis Z, Sukhova G, Lark M, Libby P. Increased expression of matrix metalloproteinases and matrix degrading activity in vulnerable regions of human atherosclerotic plaques. J Clin Invest 1994; 94: 2493-503.

[116] Eckart R, Uyehara C, Shry E, Furgerson J, Krasuski R. Matrix metalloproteinases in patients with myocardial infarction and percutaneous revascularization. J Interv Cardiol 2004; 17: 27-31.

[117] Gasparyan AY, Watson T, Lip GY. The role of aspirin in cardiovascular prevention: implications of aspirin resistance. J Am Coll Cardiol 2008; 51: 1829-43.

[118] Ridker PM, Hennekens CH, Buring JE. C-reactive protein and other markers of inflammation in the prediction of cardiovascular disease in women. N Engl J Med 2000; 342: 836-43.

[119] Hwang SJ, Ballantyne CM, Sharrett AR. Circulating adhesion molecules VCAM-1, ICAM-1, and E-selectin in carotid atherosclerosis and incident coronary heart disease cases. The Atherosclerosis Risk in Communities (ARIC) study. Circulation 1997; 96: 4219-25.

[120] Danesh J, Whincup P, Walker M. Low grade inflammation and coronary heart disease: prospective study and updated metaanalyses. BMJ 2000; 321: 199-204. 
[121] Pearson TA, Mensah GA, Alexander RW, et al. Centers for disease control and prevention; American heart association. Markers of inflammation and cardiovascular disease: application to clinical and public health practice: a statement for healthcare professionals from the Centers for Disease Control and Prevention and the American heart association. Circulation 2003; 107: 499511.

[122] Meier-Ewert HK, Ridker PM, Rifai N. Absence of diurnal variation of C-reactive protein concentrations in healthy human subjects. Clin Chem 2001; 47: 426-30.

[123] Rifai N, Tracy RP, Ridker PM. Clinical efficacy of an automated high-sensitivity C-reactive protein assay. Clin Chem 1999; 45: 2136-41.

[124] Ridker PM. Clinical application of C-reactive protein for cardiovascular disease detection and prevention. Circulation 2003; 107 : 363-9.

[125] Ridker PM, Rifai N, Rose L. Comparison of C-reactive protein and low-density lipoprotein cholesterol levels in the prediction of first cardiovascular events. N Engl J Med 2002; 347: 1557-65.

[126] Ridker PM, Buring JE, Cook NR. C-reactive protein, the metabolic syndrome, and risk of incident cardiovascular events: an 8-year follow-up of 14719 initially healthy American women. Circulation 2003; 107: 391-7.

[127] Fiotti N, Di Chiara A, Altamura N, et al. Coagulation indicators in chronic stable effort angina and unstable angina: relationship with acute phase reactants and clinical outcome. Blood Coagul Fibrinolysis 2002; 13: 247-55.

[128] Brunetti ND, Troccoli R, Correale M, Pellegrino PL, Di Biase M. $\mathrm{C}$-reactive protein in patients with acute coronary syndrome: correlation with diagnosis, myocardial damage, ejection fraction and angiographic findings. Int J Cardiol 2006; 109: 248-56.

[129] Mueller C, Buettner HJ, Hodgson JM, et al. Inflammation and long-term mortality after non-ST elevation acute coronary syndrome treated with a very early invasive strategy in 1042 consecutive patients. Circulation 2002; 105: 1412-5.

[130] Kim H, Yang DH, Park Y, et al. Incremental prognostic value of Creactive protein and $\mathrm{N}$-terminal proB-type natriuretic peptide in acute coronary syndrome. Circ J 2006; 70: 1379-84.

[131] Hansson GK, Robertson AK, Söderberg-Nauclér C. Inflammation and atherosclerosis. Annu Rev Pathol 2006; 1: 297-329.

[132] Moubayed SP, Heinonen TM, Tardif JC. Anti-inflammatory drugs and atherosclerosis. Curr Opin Lipidol 2007; 18: 638-44.

(C) Abbasi and Boroumand; Licensee Bentham Open.

This is an open access article licensed under the terms of the Creative Commons Attribution Non-Commercial License (http://creativecommons.org/licenses/ by-nc/3.0/) which permits unrestricted, non-commercial use, distribution and reproduction in any medium, provided the work is properly cited. 